\title{
Correção cirúrgica de ruptura retal com auxílio de endoscópio: relato de caso
}

Sarah Maria Godtfredsen;, Victor Ferreira Ribeiro Mansur, Rodrigo Norberto Pereira, Eduardo Alves Lima

Universidade Federal de Lavras (UFLA), Lavras, MG, Brasil

*Autor correspondente

e-mail: sarahgodtfredsen@hotmail.com

\section{Resumo}

As lacerações de reto em equinos são classificadas em quatro graus distintos, de acordo com a gravidade da lesão. As lacerações de grau I cursam com a ruptura da mucosa e submucosa retal; as de grau II ocorrem quando somente a musculatura é rompida; nas lesões classificadas em grau III ocorre a ruptura da mucosa, submucosa e musculatura, onde apenas a serosa se matem íntegra; e as lacerações de grau IV correspondem a lesões onde todas as camadas do reto estão rompidas. Uma égua Mangalarga, 8 anos de idade, foi encaminhada ao Hospital Veterinário com histórico de sangramento retal profuso após cobertura. À palpação transretal, detectou-se uma laceração de reto grau III, dorso-lateral esquerdo com aproximadamente $6 \mathrm{~cm}$ de diâmetro, localizada a $50 \mathrm{~cm}$ oral ao ânus. A abdominocentese apresentou líquido turvo com 380.000 leucócitos/dl. A paciente foi submetida à sedação com detomidina (0,02 mgkg) e butorfanol $(0.01 \mathrm{mgkg})$, seguida de anestesia epidural com lidocaína. Foi realizada colonoscopia com endoscópio flexível. A limpeza da área lacerada foi feita com solução de Riger com Lactato e delicado debridamento com gaze. Para evitar o acúmulo de fezes no local e possível evolução da laceração para grau IV, optou-se por realizar uma sutura de aproximação das bordas da ferida. Para tanto, utilizou-se três fios de poliamida $(0,60 \mathrm{~mm}$ de diâmetro/120 cm de comprimento) aplicados com uma agulha cilíndrica, introduzido no reto protegida pela mão do cirurgião. Após passar pelas bordas da ferida, a ponta dos fios era puxada até sair pelo ânus. Os nós corrediços, portanto, foram confeccionados na área externa da paciente e introduzidos no reto, fazendo-os deslizar até a ferida. Todo o procedimento foi realizado com o auxílio da endoscopia flexível. As longas pontas dos fios de sutura foram mantidas na luz do reto para facilitar sua posterior remoção aos 14 dias de pós-operatório. A remoção da sutura também foi realizada com auxílio da endoscopia flexível. Durante o pós-operatório, foi realizada remoção manual das fezes, administração de ceftiofur $5 \mathrm{mg} / \mathrm{kg} \mathrm{IM}$ BID, metronidazol $20 \mathrm{mg} / \mathrm{kg}$ VO TID, gentamicina 6,6 mg/kg BID e flunixin meglumine $1 \mathrm{mg} / \mathrm{kg}$ IV BID. 
A paciente foi mantida com os cascos e quartela imersos em água com gelo por 36 horas, visando prevenir o desenvolvimento de laminite. Foram adicionados à dieta semente de linhaça e Muvinlax ${ }^{\circledR}$ para promover o amolecimento das fezes. 0 tratamento foi bem sucedido, pois não houve complicações sistêmicas, cursando com boa cicatrização da ferida e consequente alta da paciente.

Palavras-chave: Fístula. Ânus. Égua. 